\title{
Gender, sexuality and medical education: experiences in a federal school that uses active learning methodologies
}

\author{
Gênero, sexualidade e educação médica: vivências em uma escola federal que utiliza metodologias ativas de \\ aprendizagem
}

\author{
Pedro Mendonça de Oliveira' 1 (1) $\mid$ pedrocsnc@gmail.com \\ Aline Guerra Aquilante ${ }^{1}$ (D) aline@ufscar.br \\ Rodrigo Otávio Moretti-Pires² (1) rodrigo.moretti@ufsc.br \\ Sueli Fátima Sampaio' (D) sufasampaio@gmail.com
}

\begin{abstract}
Introduction: Sexuality is characterized as a device of power and Medicine plays a key role as one of the main action institutions. Medical education tends to ratify the heteronormative discourse and diagnose deviant patterns as a pathology. It is based on the binary categorization of individuals as an implication of their sexuality. The assessed medical course assumes the methodological proposal of the constructivist spiral, which seeks to guarantee the protagonism of the students, as well as the dialogue with their previous knowledge, using the concept of Meaningful Learning. Objective: To analyze the students' experiences in the development of the competence profile related to gender and sexuality during medical school. Method: It is a qualitative research using focus groups with students attending the sixth year of the medical course.

Result: The study indicates the students' perception of the importance of active methodologies, as well as the early inclusion in the fields of practice. However, the thematic of gender and sexuality needs to be proposed in the list of triggers for the use of the constructivist spiral.

Conclusion: The active teaching-learning methodologies can constitute a counter-hegemonic strategy in the face of the device of sexuality in guaranteeing biopower, as there is a reorientation of these contents in the curriculum.
\end{abstract}

Keywords: Medical Education; Curriculum; Problem-Based Learning; Gender Identity; Sexuality.

\section{RESUMO}

Introdução: A sexualidade se caracteriza como dispositivo de poder, e a medicina tem importante papel como uma das principais instituições de ação. A educação médica tende a ratificar o discurso heteronormativo e diagnosticar os padrões desviantes como patologia. Pauta-se na categorização binária dos indivíduos como implicação de sua sexualidade. O curso de Medicina investigado assume a proposta metodológica da espiral construtivista, que procura garantir o protagonismo dos estudantes, assim como dialoga com seus conhecimentos prévios, apostando no conceito de aprendizagem significativa.

Objetivo: Este estudo teve como objetivo analisar as experiências dos estudantes no desenvolvimento do perfil de competência relacionado a gênero e sexualidade durante o curso de Medicina.

Método: Trata-se de pesquisa qualitativa utilizando grupos focais com estudantes do sexto ano do curso.

Resultado: $O$ estudo aponta para a percepção dos estudantes sobre a importância das metodologias ativas, bem como sobre a inserção precoce nos campos de prática. No entanto, a temática sobre gênero e sexualidade precisa estar proposta no elenco de disparadores para o uso da espiral construtivista.

Conclusão: As metodologias ativas de ensino-aprendizagem podem se configurar como estratégia contra-hegemônica ante o dispositivo da sexualidade na garantia de biopoder, na medida em que haja reorientação desses conteúdos no currículo.

Palavras-chave: Educação Médica; Currículo; Aprendizagem Baseada em Problemas; Identidade de Gênero; Sexualidade.

\footnotetext{
1 Universidade Federal de São Carlos, São Carlos, São Paulo, Brazil.

${ }^{2}$ Universidade Federal de Santa Catarina, Florianópolis, Santa Catarina, Brazil.
}

Chief Editor: Daniela Chiesa.

Associate editor: Daniela Chiesa.

Received on 07/12/20; Accepted on 09/13/21.

Evaluated by double blind review process. 


\section{INTRODUCTION}

Life in society is marked by different dynamics and exercises of power, aspects that often escape the perception of physicians in their professional practice. Michel Foucault ${ }^{1}$ analyzes that both Medicine and Sexuality participate in important social processes. Regarding what the author calls the device of sexuality, the construction of knowledge and practices involved in the provision of health services and care starts from certain epistemological questions that have guided Western society since the $17^{\text {th }}$ century. In this context, the emergence of rules and norms, knowledge and surveillance has supported institutions (especially the church and the family) that were used as support to corroborate a progressive internalization process of regulations regarding the exercise of sex and social life.

An important contribution by Foucault to the understanding of the relationship between Medicine and the control of sexuality refers to how certain knowledge and the lack thereof, about the use of bodies and pleasures were privileged objects of medical study, attention and intervention, especially regarding the psychiatrization of sexuality. In the same process, the relationship between male and female in the Western society is essential to understand both the socially constructed roles and the established power hierarchies, as defended by Joan Scott ${ }^{2}$. This author discusses the perception of sexual differences and how they are used to differentiate roles in society through cultural meanings and, consequently, placing them in hierarchical relationships.

On the other hand, the political philosopher Judith Butler ${ }^{3}$ analyzes that gender is about "a set of repeated acts within a highly rigid regulatory structure, which crystallizes over time to produce the appearance of a substance, a natural class of being" ${ }^{\prime 3}$.

Butler $^{3}$ defends that identity is ensured by stabilizing concepts of sex, gender and sexuality. What is incoherent and discontinuous is also questionable, since "(...) 'people' only become intelligible by acquiring their gender in accordance with the recognizable standards of gender intelligibility" ${ }^{\prime \prime}$. Based on this context, a stable and oppositional heterosexuality is required, within the binarism.

Based on these concepts, sexuality has an important foundation in Medicine, with the power to pathologize assumed deviations, as well as to reinforce "healthy" behaviors, a movement that is almost never noticeable on the part of those who practice the profession ${ }^{1,4}$. Medical courses are based on content with epistemological bases in binary and heteronormative categories so that, when approaching patients, everything that diverges from that is made invisible or considered a deviation and disease.

The National Curriculum Guidelines for Medical Courses ${ }^{5}$ urge that curricular and extracurricular strategies centered on the learning of competences for the care of people must be guaranteed from a broader perspective. However, there is little specificity of aspects such as gender and sexuality, even though there is resonance with what is registered about professional health education in the National Comprehensive Health Policy for Lesbians, Gays, Bisexuals, Transvestites and Transsexuals - LGBT'

Moretti-Pires ${ }^{7}$, in a study with heterosexual and LGBT medical students, points to the suppression of gender and sexuality aspects in medical education. At the same time, the official curriculum of the courses, as well as the hidden curriculum, leads to the reinforcement of attention based on a certain paradigm that conceives heterosexuality, cisgenderism and the obliteration of the feminine as normal, except regarding the aspects related to reproduction.

The medical profession has a key role in issues involving sexuality and all the consequences that can originate from it, both as a device of biopower in the regulation of sexualities and a factor of self-knowledge and health. Thus, this study aims to analyze, from the perspective of the students, how the development of the competency profile related to gender and sexuality is performed during a medical course that uses activelearning methodologies.

\section{METHODS}

The research was developed in the Medical Course of Universidade Federal de São Carlos (UFSCar), which has 40 openings per year, and uses active teaching-learning methodologies in the course since its implementation in $2006^{8}$. The Constructivist Spiral (CS) ${ }^{9}$, derived from ProblemBased Learning (PBL) and problematization, gives students their protagonism in the learning process, investing in the acquisition of knowledge through metacognition and metalearning, anchoring new contents and meanings to the students' own previous knowledge repertoires. These are assumptions and foundations of the Meaningful Learning Theory ${ }^{10}$, which considers the teacher's role as a facilitator of the learning process ${ }^{11}$.

This is a descriptive, qualitative research, which deals with the interpretive understanding of social action, the intelligibility of these phenomena and the meaning and intentionality attributed to them by the involved actors ${ }^{12}$. Its focus is to question a positivist model in search of objective truths that, added to the moralization around sexuality, impairs the understanding of its own complexity ${ }^{13}$.

To reach such understandings, the study used the focus group technique as a method to collect information ${ }^{14}$, as this is a group with homogeneous identity characteristics, who share the same experience: being medical students at UFSCar. 
All forty students attending the $6^{\text {th }}$ year/2019 of the medical course of UFSCar were invited to participate in the focus groups. Fifteen students accepted and were available to participate, who were divided into 2 focus groups containing 6 and 9 participants. Distribution was guided by student availability, according to the compatibility with other scheduled medical internship activities.

Table 1 shows the composition of the focus groups.

A semi-structured script was used, previously assessed with a pilot group consisting of six students who had recently graduated from medical school. In addition to the three triggering questions that were initially considered, a fourth question was added to be worked on with the sixthyear students:

1) I would like you to report how issues of gender and sexuality are learned during the UFSCar medical course.

2) At what times did issues related to gender and sexuality appear during theoretical and practical activities? How would you describe the approach of teachers and preceptors about them?

3) In your perception, how have the curricular activities conducted through active methodologies influenced the approach to these contents?

4) Did you experience or witness any situations during the course (theoretical or practical meetings) in which, when talking about these topics, someone involved (students, patients, teachers, etc.) seemed to be embarrassed by them? If so, could you describe them?

The focus group sessions were recorded and, later, the information was transcribed and coded. The following coding was used to preserve the identity of the participants, according to their self-declaration: the initial letter $\mathrm{M}=$ Male, $\mathrm{F}=$ Female. The second letter $\mathrm{H}=$ Heterosexual, while $\mathrm{B}=$ Bisexual, $\mathrm{G}=\mathrm{Gay}$ and $\mathrm{L}=$ Lesbian. After the hyphen, come the numbers of the groups $G 1$ and $G 2$, according to the sequence in which they occurred. It is understood that the set of these characteristics help to understand the type of speech sensitivity, as well as the "place of speech" of each participant. In this sense, it is essential to register that all participants are cisgender people and that none of the groups included transexual participants (binary or non-binary).

To analyze the information, the Method of Interpretation of Meanings ${ }^{15}$ was used. Due to its socio-anthropological perspective, this method focuses on the cultural phenomenon. Its trajectory of analysis of meanings is determined by the comprehensivist currents of the social sciences and considers words; actions; set of interrelationships; groups;
Table 1. Characterization and distribution of research participants.

\begin{tabular}{ccccc}
\hline \multirow{2}{*}{ Identification } & Women & Men & Total \\
\hline \multirow{3}{*}{ Group 1 } & Homosexuals & 0 & 0 & 0 \\
& Bisexuals & 3 & 0 & 3 \\
& Heterosexuals & 1 & 2 & 3 \\
\hline \multirow{3}{*}{ Group 2 } & Homosexuals & 0 & 2 & 2 \\
& Bisexuals & 2 & 1 & 3 \\
& Heterosexuals & 2 & 2 & 4 \\
\hline \multirow{6}{*}{} & Total & 8 & 7 & 15 \\
\hline
\end{tabular}

institutions; conjunctures, among other analytical fields. Thus, the information collected during the interviews was analyzed following the three steps provided by the Method of Interpretation of Meanings:

1) Description: after the literal transcription of the material and immersive readings, a descriptive synthesis of the main aspects and a preliminary definition of the analysis categories were produced;

2) Analysis: as this is a movement of decomposition of the descriptive synthesis, a systematic path that sought explicit or not explicit key locators was outlined in the participants' statements. The product of this phase was a broader synthesis, which establishes relationships between the factors in the statements and consolidates the choice of the analytical categories;

3) Interpretation: a step that seeks meaning in speeches and actions to achieve understanding or explanation beyond the limits of what is described and analyzed. The product of this phase is a synthesis that articulates the analysis of the statements with the adopted theoretical references ${ }^{1-3}$.

It is noteworthy that these three phases of qualitative data processing do not have clear boundaries between them. The important thing is to seek the group's internal logic, given the topic that is being analyzed.

This study was assessed and approved by the Research Ethics Committee of Universidade Federal de São Carlos, (Opinion: 3.045.004, of 11/28/2018), meeting the requirements of Resolution n. 466/2012 of the Brazilian National Health Council.

\section{RESULTS}

Group 1 consisted of six students from the same medical internship group, that is, who performed all practical internships together. The focus group was conducted during the interval between activities at the University Hospital. As described in 
Table 1, it consisted 4 women (3 bisexual and 1 heterosexual woman) and 2 men (heterosexuals), and not necessarily all of them had any affinity or aroused interest in the topics. The discussions offered by this group were prominent in terms of the gender topic, with a significantly greater volume of speech among the women of the group. Aspects related to sexuality did not arise spontaneously, being elicited by the moderator.

In contrast, group 2 was more heterogeneous, both in terms of gender and sexual orientation, with 2 gay men, 1 bisexual man, 2 heterosexual men, 2 bisexual women and 2 heterosexual women. This group consisted of students with a closer relationship with the topics, whose participants were individually organized to conduct the group meeting on a date and time suggested by the researcher, having managed to encompass both gender and sexuality without the need for intervention. There was no greater tendency towards monopolizing the discussion for one of the two topics. It was understood that all participants had the opportunity to contribute without the need to be encouraged.

Although the course curriculum employs active methodologies, there is a lack of direct approach about gender and sexuality in the disciplines during undergraduate school, according to the students' perception. However, although there is a consensus among the participants that there is no activity specifically aimed at such topics, that is, this is not part of the curriculum in the Curricular Activities, the trajectory of insertion in the field of practice throughout the undergraduate years has put them in contact with issues of gender and sexuality. In this sense, the directive use in terms of active methodologies could promote greater security when dealing with this issue, since the creation of bonds with patients is one of the most interesting approaches according to the interviewed students.

Actually, in our curriculum, we do not formally have contact, a discussion in this sense, it is a little more directed towards having $a$, that is... to adequately conduct an anamnesis, a behavior and to create an adequate bond with the patient. (FH-G2)

I think we gain maturity throughout the course and now we have more security to deal with this topic. So, if it appeared in my first year, in the first exposure, I would be more uncomfortable, and now in the sixth year I have more confidence in dealing with patients about these issues, but it is not like we were specifically trained for this. It is the training to be a physician. (FB-G1)

Despite the gains in terms of openness to questioning and uncertainty that students registered through the use of Active Methodologies, it should be noted that concepts specific to the area of gender and sexuality are not familiar to future male and female physicians. This often implies problems for more technical actions in the specifics of LGBTI+ health, as well as for building bonds. There was little fluidity or familiarity of students in the treatment of certain inherent specificities, especially regarding the way to conduct medical interventions, even in situations such as transgender pregnancy.

I think the active methodology teaches us this, that it is not wrong not to know, and it is okay for me to ask, as long as I ask with the real objective of helping the patient. (MG-G2)

In the maternity ward, we treated a pregnant woman, she was actually trans, and she was pregnant and her partner... I don't remember exactly what it was like, but the partner was also a man, right... he was cis and homosexual... . she was a woman... she was a trans man, and homosexual... and she was pregnant, right... he was pregnant... (FB-G1)

The power to employ the early inclusion of students in real practice scenarios seems to be related to the perception of preparation regarding the doctor-patient relationship. The educational experience of students from the first year of the course allows building a unique, ethical and more humanized relationship for health care. Thus, it can be the basis for the entire undergraduate school and professional life. This is recognized and valued by them (students), especially when analyzed in contrast to what happens in other institutions with more traditional curricula ${ }^{16}$. It is noteworthy that this potential can be of foremost importance when addressing gender and sexuality aspects in medical care, if these dimensions of patients' experiences are addressed in a way that is articulated with the teaching of medical practice.

I think that the early inclusion into practice makes us develop an interpersonal relationship, reaching the sixth year with a much more polished interpersonal relationship than in other schools, which have the main part during internship, within 2 years. This allows us to reach out to the person and ask questions much more naturally, treating them naturally. (MB-G2)

From the participants' perception, the use of active methodologies is related to a behavior that they understand as a proactive search for knowledge. Synergistically, the gain of autonomy also makes students pursue knowledge when situations experienced in practice dialogue with their previous experiences, an essential characteristic of the concept of meaningful learning.

I think the active methodology helps us to develop a critical sense and a willingness to search for knowledge, which is great, right. Pro-active, definitely. (FB-G1)

It is noteworthy that, despite the dissemination of the topic of the research project, it was necessary to bring to the discussion of one of the groups the agenda of how issues of 
gender and sexuality are (not) covered during the course. It was registered that the triggers of this topic come from the stages experienced in the Curricular Activity "Professional Practice". As the participants pointed out, several broader aspects of the user's life, including gender and sexuality, do not appear as explicit curricular content. Therefore, for many, this training depends on their own search, on the experiences in a medical practice linked to the topic, as well as on other aspects less explored in medical education.

Several aspects of Medicine are not adequately considered mandatory in our course, but it does predict that we will see this in our practice. So, with a better reflection, I think that the course provides this for us. Because it is very difficult for you to spend six years in contact with practice and not have a discussion about it. (MH-G2)

Yes, I really think that when we study life cycles, which is something well situated in the early years, the issue of sexuality comes up, without a doubt, right. So, making this deeper reflection, I think it appears somehow, yes, and in a slightly more predicted way than we were talking about. (MG-G2)

If you are not exposed at some point in the course either, you don't have a schedule to prepare you for later. I don't remember having an activity that prepares you for this... In my case, as I came here a little older, I can see that there is greater sexual diversity than I imagined before entering medical school. But I believe the university did not prepare me, did not give me classes on how to deal with this. (MH-G1)

Despite the silencing of spaces and formative discussions in terms of gender and sexuality, the relevance of the topic for medical education was pointed out as part of the participants' concern. This occurs, especially, when working with methods that allow the approach of patients in a non-stigmatizing way, that guarantee broader care and that include these dimensions.

I think that if our problem-situations (PS), if they want to be a reflection of society, I think it would be very easy to include homosexual couples in the PS, because as long as we don't treat them in a normal way, it will always be a taboo, we will always find it difficult to talk about this. Because it is something that we will experience in practice, so I believe this would be a way of including the subject in the undergraduate course. In the same way that, nowadays, gay couples are showing up in soap operas and so on... (MB-G2)

I think that what scares me about the inclusion of these topics is precisely the stigma. For instance, when a lesbian patient appeared, she had PCOS (Polycystic Ovary Syndrome), she had more masculine features, "between quotations." And I think I am afraid of that, for instance, of a homosexual couple in the AIDS PS (problem situation). (FB-G2)

\section{DISCUSSION}

The fact that there is no curricular activity directed to the topics of gender and sexuality resonates to the findings of Moretti-Pires ${ }^{7}$, a study that disclosed marked silence on the topic in the education of medical students from another federal university. This other course is conducted using the traditional teaching methodologies and, according to the students, it did not have anything related to gender and sexuality in the disciplines either, which is interesting to point out that the active methodologies themselves do not account for the various aspects of reality and of society.

The understanding of the active methodology externalized by the research participants denotes a crucial point of contact with the idea of the dialogic approach to competency ${ }^{17}$. Another very significant result contrasts with the findings by Moretti-Pires ${ }^{7}$ about the students' attitude towards the challenge of learning. While the research subjects reveal a position of comfort in the face of doubt, which according to the students' own speech is an unfolding of the active methodology, the perception of medical students submitted to traditional curricula and methodologies is that doubts should not exist. There is the impression that just by being a medical student, one assumes that you should know everything in advance. Moreover, questions are generally not welcome, especially if directed at the teachers. Students are not taught to problematize either their knowledge or their practice, which makes that context an impoverished space in relation to criticism and reflection.

What is found in this study may appear as a break in the paradigm of medical education indicated by Foucault and reinforced by the Moretti-Pires' thesis, in which silencing the student in the classroom is a teacher's function. According to Foucault", "medical security is embedded in the network built by the bundle of relationships and meanings that operate the biopower"; therefore, it is necessary to use the "hierarchical surveillance", a progressive and present hierarchy, but working in "silence". In the silence learned by the student. In the silence of those who are hierarchically inferior.

The National Comprehensive Health Policy for Lesbians, Gays, Bisexuals, Transvestites and Transexuals formally recommends the inclusion of curricular content related to LGBT health as a mandatory topic, which includes: basic terminology related to the LGBT population, interview questions that facilitate the opening of the topic of sexual orientation and gender identity, information about the impact of heterosexism and homophobia, as well as the need for specific health care of minority populations about gender and sexual identity ${ }^{6}$. What was observed in this study confirms the reiterated importance of integrating the LGBT health topic in a mandatory way and 
of developing support mechanisms for the pedagogical structuring of the content, aiming to help the curricular activities to fulfill their role.

It is possible to infer that students assume the relevance of the topics, without understanding them as pathologies. During the group discussions, ways of including these subjects into the Curricular Activities were naturally debated, that is, without prejudice or judgment of value.

Regarding learning from problem situations (PS), which has as its primary function, in the constructivist spiral movements, to provide elements for creating learning hypotheses and questions, the students demonstrated that they had good knowledge about how they should be worked. For this to happen, according to Lima and Linhares ${ }^{18}$, the PS must contain:

...an expanded, integrated and integrative view of the essential topics to be studied, contemplating different aspects of the health-disease process [...] and identifying the biopsychosocial dimensions. For this purpose, some principles must be followed, such as: performing a description of the phenomena addressed in the problem as neutrally as possible, formulating the problem in a concrete way, minimizing the text distractors, guiding the learning to a limited number of items, and containing items that use the students' prior information.

This study does not aim to discuss the teachers' capacity to prepare and conduct curricular activities through the strategies provided for in active methodologies, such as PS, although for some authors, such as Tomaz ${ }^{11}$, the expertise in the facilitation process is more important than the expertise in the topic to be studied. It is also important to note that almost all academics on the subject agree that some degree of approximation with the topic is desirable, sufficient to allow the group to be redirected in cases in which discussions deviate from the axis proposed by the problem.

Although the courses are trying to restructure their pedagogical projects regarding the health of marginalized populations, there are some authors who believe there are still no answers about the best methodologies to be employed to achieve the proposed objectives ${ }^{19}$.

It is relevant to comment that the virtual inexistence of specific training for teachers in the pedagogical field in medical schools is widely recognized. Competency in the technical area of medical practice has been the essential criterion for the selection or election of professionals who will go from physicians to researchers and teachers. This implies the existence of a profound lack of knowledge of teaching techniques and methodologies, working with groups and producing appropriate teaching materials ${ }^{20}$.
The main focus of the present article is the topic of gender and sexual diversity in medical education, an agenda that has gained visibility in society based on feminist agendas. In this sense, gender inequalities and inequities impact people's health. It should be considered that situations of gender-based violence should be discussed in medical education with a focus on the experiential processes and relationships of women in the external, domestic scenario and in intimate relationships, with increased sensitivity and with a view of future physicians for these other dimensions of the issues presented herein.

\section{CONCLUSIONS}

The results indicated important advances in terms of medical training regarding the use of active methodologies and in contact with reality. However, it indicates the need for actions and strategies that are more directed to the discussion of gender and sexuality when approaching patients during the course as a whole. The training was somewhat spontaneous and indirect, which does not necessarily guarantee the same opportunity for all students, since the concepts of gender and sexuality were not mobilized in a fluid and integrated manner into medical practices, including the need for greater clarification to trigger the discussion in one of the focus groups.

The early inclusion of students into the reality of practice was identified as a positive fact, with enormous potential for approaches that take into account other dimensions of the patient's life, including gender and sexuality issues.

Although still relatively irrelevant regarding their volume at national level, publications involving gender and sexuality have gained space in journals and publications. This study brings important contributions about possible paths to be followed, with regard to the power of teaching-learning methodologies when approaching such topics.

\section{AUTHORS' CONTRIBUTION}

Pedro Mendonça de Oliveira was responsible for the study design, literature review, data production and analysis, writing of the manuscript and approval of its final version. Aline Guerra Aquilante supervised the Master's Degree dissertation of Pedro Mendonça de Oliveira and participated in the study design, writing and approval of the final version of the manuscript. Sueli Fátima Sampaio and Rodrigo Otávio Moretti Pires collaborated with the study design, writing and approval of the final version of the manuscript.

\section{CONFLICTS OF INTEREST}

The authors declare no conflicts of interest. 


\section{SOURCES OF FUNDING}

The publication fee was financed by the Postgraduate Program in Clinical Management of the Federal University of São Carlos (UFSCar).

\section{REFERENCES}

1. Foucault M. História da sexualidade 1: a vontade de saber. Rio de Janeiro: Paz e Terra; 2015.

2. Scott J. Gênero: uma categoria útil de análise histórica. Educ Real. 1990;15(2):5-22.

3. Butler J. Problemas de gênero: feminismo e subversão da identidade. Rio de Janeiro: Civilização Brasileira; 2015.

4. Davy Z. Recognizing transsexuals: personal, political and medicolegal embodiments. London: Ashgate; 2011.

5. Brasil. Resolução CNE/CES $n^{\circ}$ 3, de 20 de junho de 2014. Diretrizes Curriculares Nacionais do Curso de Graduação em Medicina. Brasília: Ministério da Educação; 2014.

6. Brasil. Política Nacional de Saúde Integral de Lésbicas, Gays, Bissexuais, Travestis e Transexuais. Brasília: Ministério da Saúde; 2011.

7. Moretti-Pires RO. Domesticando corpos, construindo médicos: das relações de gênero a uma sociologia da profissão [dissertação]. Florianópolis: Universidade Federal de Santa Catarina; 2017.

8. Adler MS, Gallian DMC. Escola médica e o Sistema Único de Saúde (SUS): criação do curso de Medicina da Universidade Federal de São Carlos, SP, Brasil (UFSCar) sob a perspectiva de docentes e estudantes. Interface (Botucatu). 2016;22(64):237-49.

9. Lima VV. Espiral construtivista: uma metodologia ativa de ensinoaprendizagem. Interface (Botucatu). 2017;21(61):421-34.

10. Ausubel D. Aquisição e retenção de conhecimentos: Uma perspectiva cognitiva. Lisboa: Plátano Edições Técnicas; 2000.
11. Tomaz JB. O papel e as características do professor. In: Mamede S, Penaforte J, organizadores. Aprendizagem baseada em problemas: anatomia de uma nova abordagem educacional. São Paulo: Hucitec; 2001. p. $157-82$.

12. Minayo MCS. Pesquisa social: teoria, método e criatividade. Petrópolis: Vozes; 1993.

13. Gamson J. As sexualidades, a teoria queer e a pesquisa qualitativa. In: Denzin NK, Lincoln YS, organizadores. O planejamento da pesquisa qualitativa. Porto Alegre: Artmed; 2010. p. 145-60.

14. Deslandes SF. Trabalho de campo: construção de dados qualitativos em quantitativos. In: Minayo MCS, Assis SG, Souza ER, organizadoras. Avaliação por triangulação de métodos: abordagem de programas sociais. Rio de Janeiro: Fiocruz; 2006. p. 157-84.

15. Gomes R, Souza ER, Minayo MCS, Malaquias JV, Silva CFR. Organização, processamento, análise e interpretação de dados: o desafio da triangulação. In: Minayo MCS, Assis SG, Souza ER, organizadoras. Avaliação por triangulação de métodos: abordagem de programas sociais. Rio de Janeiro: Fiocruz; 2006. p. 185-222.

16. Gonçalves JV, Gonçalves RC, Silva RF. Cuidado à saúde e a formação do profissional médico. Rev Bras Educ Med. 2018;42(3):9-15.

17. Lima VV. Competence: different approaches and implications in the training of healthcare professionals. Interface Comun Saúde Educ. 2005;9(17):369-79.

18. Lima GZ, Linhares REC. Escrever bons problemas. Rev Bras Educ Med. 2008;32(2):197-201.

19. Oliveira MFR, Castanho JLCO, Rorigo SC. Saúde e marginalização social: suprimindo falhas curriculares. Rev Bras Med Fam Comunidade. 2019;14(41):1793. doi: 10.5712/rbmfc14(41)1793.

20. Feuerkewer LC. Além do discurso de mudanças na educação médica. São Paulo: Hucitec; 2000. p.10-44. 